\title{
Indicators of surgical patients after the implementation of an Internal Bed Regulation Committee in a university hospital*
}

\author{
Indicadores de paciente cirúrgico após implantação de Núcleo \\ Interno de Regulação de Leitos em hospital universitário \\ Indicadores de los pacientes quirúrgicos tras la implantación del Comité \\ Interno de Regulación de Camas en un hospital universitario
}

How to cite this article:

Maldonado RN, Feijó VBER, Balsanelli AP, Ribeiro RP, Rossaneis MA, Haddad MCFL. Indicators of surgical patients after the implementation of an Internal Bed Regulation Committee in a university hospital. Rev Esc Enferm USP. 2021;55:e03719. doi: https://doi.org/10.1590/S1980-220X2020001903719

Rayane Nascimbeni Maldonado ${ }^{1}$

Vivian Biazon El Reda Feijó ${ }^{1}$

Alexandre Pazetto Balsanelli²

Renata Perfeito Ribeiro ${ }^{1}$

Mariana Angela Rossaneis

Maria do Carmo Fernandez Lourenço Haddad ${ }^{1}$

* Extracted from the dissertation: "Indicadores de paciente cirúrgico após a implantação de Núcleo Interno de Regulação de Leitos em hospital universitário", Universidade Estadual de Londrina, 2019.

1 Universidade Estadual de Londrina,

Departamento de Enfermagem,

Londrina, PR, Brazil.

2 Universidade Federal de São Paulo, Escola

Paulista de Enfermagem, São Paulo, SP, Brazil

\begin{abstract}
Objective: To analyze the indicators of surgical patients after the implementation of an Internal Bed Regulation Committee in a university hospital. Method: Longitudinal, quantitative, and retrospective study. The data collection was conducted in the Hospital Management Information institutional system, from which the information of patients submitted to surgical procedures from January 2015 to June 2018 were obtained. To verify the data trends, a simple linear regression model was used. Results: The predominance of patients aged 20 to 39 and hospitalized on an emergency basis was observed. An ascending trend for structure indicators was verified regarding the number of surgical procedures and patients per surgical room. The process indicators were stagnant. An ascending trend was presented by the result indicators related to the number of surgical patients, hospitalized surgical patients, surgical procedures, and patients with Hospitalization Authorization. Conclusion: A change in the mean values of the process indicators was observed, showing the performance of this service. Organizational changes were also observed regarding the establishment of norms, processes, and flows.
\end{abstract}

\section{DESCRIPTORS}

Bed Occupance; Surgicenters; Indicators of Health Services; Hospital Administration; Operating Room Nursing. 


\section{INTRODUCTION}

According to the Brazilian National Association of Private Hospitals (Associação Nacional de Hospitais Privados - ANAHP), the Unified Health System (Sistema Único de Saúde - SUS) had a reduction of 11,938 beds from 2008 to $2013^{(1)}$. However, the demand for health care services has been growing, requiring an efficient management of the installed capacity to overcome hospital overcrowding ${ }^{(2)}$.

The insufficiency of beds culminates in a delay in patient admission in emergency services, suspended elective surgeries, inappropriate use of beds, and flawed flow of transference among care units, with a repercussion mainly on discharges of intensive care units $^{(3)}$ and in the increase in patient stay in Post-Anesthesia Care Units (PACU). Consequently, patient stay in hospital is increased and bed turnover, surgical productivity, and quality of care are reduced ${ }^{(4)}$.

With the objective of broadening the efficacy of the use of hospital beds and reducing the mentioned problems, a tendency for implementing patient flow management systems is observed among health institutions ${ }^{(5)}$. The implementation of these systems is emphasized to help tracking indicators and planning hospital occupancy, contributing also to the optimization of admission processes until patient discharge $\mathrm{e}^{(3,6)}$.

In this context, the bed management system has emerged as an important part of planning the operational capacity, control, and efficient use of resources. This tool promotes the accommodation of patients from urgency and emergency services without jeopardizing meeting the elective demand ${ }^{(3,7)}$, considering that bed management is conducted by a professional whose instrument of work is the real-time hospital census.

In Brazil, the Ministry of Health, concerned with bed optimization, has published the Ordinance n. 1.663/2012, on the SOS Emergency Program (Programa SOS Emergência) within the Urgency and Emergency Care Network (Rede de Atenção às Urgências e Emergências), whose objective is organizing care in the emergency services, improving speed and effectivity of care ${ }^{(8)}$. The Ordinance n. 3.390/2013, on the Nacional Policy of Hospital Care (Politica Nacional de Atenção Hospitalar-PNHOSP) presents guidelines for organizing the hospital component of the Healthcare Network (Rede de Atenção à Saúde - RAS) and defines the Internal Bed Regulation Committee (IBRC) as an element of institutional coordination, responsible for managing beds in a centralized manner, with a connection between institution and its correspondent Regulation Centers ${ }^{(9)}$.

The surgical center, intensive care units, and emergency rooms are priority sectors for bed regulation, given that they are responsible for the highest patient flow of the hospital ${ }^{(10)}$. However, a surgical center with no effective bed management and scheduling management may stagnate the institution's flow ${ }^{(10)}$.

The management of beds associated with the surgical center is constituted as one of the priorities of the National Humanization Policy (Politica Nacional de Humanização$\mathrm{PNH})^{(11)}$, which aims to reduce lines and waiting time for surgeries, also providing extended access and supportive and effective care ${ }^{(12)}$.

In face of this, bed regulation services and strategies may improve hospital indicators, including those related to surgical patients, promoting, mainly, an improvement in quality of healthcare. However, a scarcity of studies relating implementation and these service's activities with changes in hospital indicators was observed.

This study's objective was thus analyzing the indicators of surgical patients after the implementation of the Internal Bed Regulation Committee in a university hospital.

\section{METHOD}

\section{Studi DESIGN}

This is a longitudinal, quantitative, and retrospective study ${ }^{(13)}$.

\section{LOCATION}

This research was conducted in a public tertiary university hospital located in the north of Paraná - PR, Brazil, which has 291 beds and is considered a regional reference in highcomplexity care, with an emphasis on high-risk pregnancy patients, victims of trauma, and burned patients.

The institution presents two Intensive Care Units (ICU) for adults, three hospitalization units for surgical and clinical patients of diverse specialties, the Infectious Diseases (ID) sector, Bone Marrow Transplantation Unit (BMTU), Burn Treatment Center (BTC), maternity, neonatal ICU, pediatric ICU, and the Emergency Treatment Unit.

The surgical center has a $1,050 \mathrm{~m}^{2}$ physical structure composed of one reception room for surgical patients, seven operating rooms (OR), one Post-Anesthesia Care Unit (PACU) and on-site pharmacy, in addition to three support rooms and attached Material and Sterilization Center (MSC).

Concerning human resources, the number of nurse technicians, which perform the functions of circulating nurse and surgical instrument assistant, administrative technicians, hygiene assistants, has presented no change, maintaining around 40 , four, and six professionals, respectively. However, the number of nurses went from six in 2016 to 12 in 2018.

As for the surgical team, the institution had as of the study collection period 92 medical residents distributed in the following specialties: anesthesiology (12), neurosurgery (5), obstetrics and gynecology (24), ophthalmology (6), otolaryngology (6), general surgery (14), orthopedics and traumatology (9), urology (3), vascular (3) and endovascular (1) surgery, pediatric surgery (3), and oral and maxillofacial traumatology (6).

For 2020, 38 medical residency positions were offered to the surgical center area, distributed into the specialties: anesthesiology (5), neurosurgery (1), obstetrics and gynecology (10), ophthalmology (2), otolaryngology (2), general surgery (7), orthopedics and traumatology (4), urology (1), vascular (1) and endovascular (1) surgery, pediatric surgery (1), oral and maxillofacial traumatology (2) and digestive system surgery (1). 
These residents are supervised by medical professors (74) with statutory employment contract (28) and outsourced service providers (49), totaling 151 professionals.

In 2019, a mean of 580 surgeries were performed per month.

The IBRC, this study's focus, was implemented in July 2016 with the objective of regulating the patient flow based on diagnostic and therapeutic resources, providing access, welcoming, and patient safety within the hospital, reducing prolonged stays. The performance of this committee for bed management integrated with clinical practice and the process of hospitalization and discharge optimizes bed occupancy and the installed capacity.

\section{DATA COLLECTION}

The data of patients submitted to surgical procedures from January 2015 to June 2018 were included.

The patients' data were collected from the Hospital Management Information system of the study institution.

The analyzed indicators referred to structure, process, and result ${ }^{(14)}$. The structure indicators were number of procedures per surgical room and number of patients per surgical room.

To analyze the process indicators, the following were considered: time between emission and authorization for the Hospital Admission Authorization (HAA), time between HAA authorization and surgery, time between hospital admission and surgery, time between surgery and hospitalization outcome (discharge/transference/death), duration of hospital stay, time in the in the surgery room, waiting time in the Post-Anesthesia Care Unit after outpatient discharge, waiting time in the Post-Anesthesia Care Unit after inpatient discharge and total time in the surgical center. All these indicators were measured in hours.

The result indicators were number of surgical patients, number of surgical inpatients, number of surgical procedures, number of patients with HAA, and surgical patient mortality rate.

\section{Data tREATMENT AND ANALYSIS}

Indicator analysis was conducted in the Statistical Package for the Social Sciences ${ }^{\varpi}$ (SPSS) program, version 20.0, through simple linear regression to verify data trends, considering the period of 18 months prior to IBRC implementation until the end of data collection, amounting to 42 months to be analyzed. A temporal model of linear regression with trend component $\left(Y=\beta_{0}+\beta_{1} X\right)$, in which $Y$ is the range of values of the time series (dependent variable), $\mathrm{X}$ refers to time (independent variable), $\beta_{0}$ corresponds to the intersection between the line and the vertical axis (constant) and $\beta_{1}$ corresponds to line inclination was employed ${ }^{(15)}$.

The adopted Null Hypothesis was $\mathrm{H} 0: \beta_{1}=0$ (dependent variable presents no change) and Alternative Hypothesis H1: $\beta_{1} \neq 0$ (variable presents change). The dependent variable referred to all indicators of structure, process, and result. The trends were classified as ascending, descending or steady in accordance with line inclination. A 5\% alpha error was adopted.

This statistical model was chosen due to the possibility of analyzing the trend of dependent variables over time, providing the verification of changes in indicators before and after the IBRC implementation.

\section{ETHICAL ASPECTS}

The research was approved by the Research Ethics Committee in Opinion n. 2.618.220, dated 2018, and abided by the ethical principles of Resolution n. 466/12 of the National Health Council.

\section{RESULTS}

The results showed that the profile of patients submitted to surgical procedures in the study institution was regular regarding age, nature of care, and surgical specialty over the evaluated period.

Individuals aged 20 to 39 represented the predominant age group (35.81\%), followed by those aged 60 or older $(22.16 \%)$. Regarding nature of care, urgency was predominant $(70.65 \%)$.

The obstetrics (19.81\%), orthopedics and traumatology (19.60\%) and surgical emergency service (10.47\%) specialties had a higher number of patients in the study period. However, the urology clinic had a $173.9 \%$ increase in relation to the number of patients receiving care after the implementation of IBRC.

The structure indicators had a significant ascending trend in the period (Table 1).

Table 1 - Trend of structure indicators from January 2015 to June 2018 in a university hospital - Londrina, PR, Brazil, 2018.

\begin{tabular}{|c|c|c|c|c|c|c|c|c|}
\hline \multirow{2}{*}{ Indicator } & \multicolumn{2}{|c|}{ Before } & \multicolumn{2}{|c|}{ After } & \multicolumn{4}{|c|}{ Trend } \\
\hline & Mean & SD & Mean & SD & $\boldsymbol{\beta}_{1}$ & $\mathbf{R}^{2}$ & $\mathrm{Cl}$ & \\
\hline N. of procedures per surgical room & 77.56 & 13.12 & 96.17 & 13.85 & $1.01^{*}$ & 0.57 & $0.73-1.28$ & \\
\hline N. of patients per surgical room & 57.49 & 8.26 & 63.86 & 8.07 & $0.37^{*}$ & 0.27 & $0.17-0.56$ & $\uparrow$ \\
\hline
\end{tabular}

Note: Ascending trend $(\uparrow)$

Concerning the process indicators (Table 2), although there was a reduction in the mean time between HAA emission and authorization, time between hospital admission and surgery, time between surgery and hospitalization outcome, time in the surgical room and duration of hospital stay, the trend was verified to be steady as per the model. This result is emphasized to be possibly related only to the analyzed period and may present ascending or descending trends in different moments.

The means for the other indicators had an increase; however, no significant temporal trend was verified. This increased mean is presupposed to be related to surgical center optimization. 
Table 2 - Trend of process indicators in the period from January 2015 to June 2018 in a university hospital - Londrina, PR, Brazil, 2018.

\begin{tabular}{|c|c|c|c|c|c|c|c|c|}
\hline \multirow{2}{*}{$\begin{array}{l}\text { Indicator } \\
\text { Time - days }\end{array}$} & \multicolumn{2}{|c|}{ Before } & \multicolumn{2}{|c|}{ After } & \multicolumn{4}{|c|}{ Trend } \\
\hline & Mean & SD & Mean & SD & $\beta_{1}$ & $\mathbf{R}^{2}$ & $\mathrm{Cl}$ & \\
\hline $\begin{array}{l}\text { Between emission and } \\
\text { HAA }\end{array}$ & 731.48 & 528.09 & 504.25 & 233.71 & -12.64 & 0.15 & $-22.22--3.06$ & - \\
\hline $\begin{array}{l}\text { Between HAA } \\
\text { authorization and surgery }\end{array}$ & 6901.96 & 1393.24 & 7159.97 & 1428.44 & 6.10 & 0.00 & $-30.37-42.57$ & - \\
\hline $\begin{array}{l}\text { Between hospital } \\
\text { admission and surgery }\end{array}$ & 83.96 & 13.97 & 67.98 & 11.85 & -0.93 & 0.58 & $-1.18--0.68$ & - \\
\hline $\begin{array}{l}\text { Between surgery and } \\
\text { hospitalization outcome }\end{array}$ & 152.53 & 24.47 & 129.92 & 18.08 & -1.13 & 0.34 & $-1.63--0.63$ & - \\
\hline Time in the surgical room & 3.08 & 0.40 & 3.03 & 0.39 & 0.00 & 0.00 & $-0.10-0.11$ & - \\
\hline $\begin{array}{l}\text { Waiting time in the Post- } \\
\text { Anesthesia Care Unit after } \\
\text { outpatient discharge }\end{array}$ & 0.65 & 0.12 & 0.66 & 0.13 & -0.00 & 0.00 & $-0.00-0.00$ & - \\
\hline $\begin{array}{l}\text { Waiting time in the Post- } \\
\text { Anesthesia Care Unit after } \\
\text { inpatient discharge }\end{array}$ & 0.68 & 0.15 & 0.69 & 0.14 & -0.00 & 0.00 & $-0.00-0.00$ & - \\
\hline $\begin{array}{l}\text { Time in the surgical } \\
\text { center }\end{array}$ & 4.37 & 0.35 & 4.55 & 0.26 & 0.01 & 0.07 & $-0.01-0.02$ & - \\
\hline Hospital stay & 236.83 & 34.03 & 198.51 & 24.97 & -2.06 & 0.53 & $-2.68--1.44$ & - \\
\hline
\end{tabular}

Note: HAA - Hospital Admission Authorization; Steady trend ( - )

An ascending trend was observed for the result indicators, except for surgical patient mortality rate, although the mean decreased after IBRC implementation (Table 3).

Table 3 - Trend of result indicators in the period from January 2015 to June 2018 in a university hospital - Londrina, PR, Brazil, 2018.

\begin{tabular}{|c|c|c|c|c|c|c|c|c|}
\hline \multirow{2}{*}{ Indicator } & \multicolumn{2}{|c|}{ Before } & \multicolumn{2}{|c|}{ After } & \multicolumn{4}{|c|}{ Trend } \\
\hline & Mean & SD & Mean & SD & $\beta_{1}$ & $\mathbf{R}^{2}$ & $\mathrm{Cl}$ & \\
\hline N. of surgical patients & 402.44 & 57.81 & 447.04 & 56.48 & $2.57^{*}$ & 0.27 & $1.22-3.92$ & $\uparrow$ \\
\hline N. of surgical inpatients & 345.00 & 45.39 & 395.67 & 45.11 & $2.70^{*}$ & 0.41 & $1.67-3.72$ & $\uparrow$ \\
\hline N. of surgical procedures & 542.94 & 91.84 & 673.21 & 96.92 & $7.04^{*}$ & 0.57 & $5.09-8.98$ & $\uparrow$ \\
\hline N. patients with HAA & 57.50 & 29.49 & 82.25 & 24.48 & $1.33^{*}$ & 0.31 & $0.70-1.96$ & $\uparrow$ \\
\hline Surgical patient mortality rate & 5.84 & 1.13 & 5.24 & 1.26 & -0.03 & 0.08 & $-0.06-0.00$ & - \\
\hline
\end{tabular}

Note: Ascending trend $(\uparrow)$, steady trend $(-)$

\section{DISCUSSION}

The actions developed by the IBRC in the study institution enable monitoring the surgical patient flow, controlling the arrival, the hospitalization process, and the internal and external movement until hospital discharge, corresponding to the directives proposed by the Ministry of Health regarding its function ${ }^{(4)}$.

With the implementation of this service, it was possible to establish the norms and the flow of surgical patients in the institution, favoring the planning of strategies for optimizing the resources to meet the high demand of patients with quality and effectivity. However, the resistance of the medical team, especially resident physicians, against the observation of new norms and routines established by the service led the results of IBRC activities to be gradual.

The inpatient profile of the institution presented no change in the studied period. Most adults were young adults from the urgency and emergency service, aged 20 to 39.
Considering that the institution is a reference in orthopedic and traumatological care, this finding is presupposed to be due to external causes. A study conducted in a university hospital of Pernambuco state, Brazil, identified that patients were 20 to 29 and were victims of traffic accidents related mainly to motorcycles ${ }^{(16)}$.

In this study, however, for both of the analyzed periods, individuals over 60 represented the second most predominant age group, which may be explained by the populational increase of elderly, considering that the growth of this population is estimated as 4\% per year from 2012 to 2022, surpassing 19.6 million in 2010 to 41.5 million in $2030^{(17)}$. An Australian public hospital has verified an increase in care provided to this population ${ }^{(18)}$, demonstrating population aging worldwide.

A study evaluating the hospitalization profile in general hospitals of the Fundação Hospitalar do Estado de Minas Gerais (FHEMIG) network has found a mean age of 54.4 years ${ }^{(19)}$. In this sense, the search for health care by the elderly 
population tends to be higher and, consequently, the hospitalization rate is also higher. As a consequence of the multiple chronic diseases which demand constant follow-up, the time of hospital stay of elderly patients may be prolonged ${ }^{(20)}$.

Urgency care was observed to be predominant, i.e., the daily flow of patients is higher in the Emergency Service (ES), and the efficient and rational use of beds in other hospital sectors is thus crucial, considering that the overcrowding of this sector is related not only to its own dysfunction, but is also a reflex of the workings of the whole institutional complex ${ }^{(2)}$.

Regarding the Emergency Service, the output step is due to actions which aim to organize and direct the care process, which may encompass discharge, transference to another institution, or hospital admission ${ }^{(2)}$. In this sense, there is a tendency to organize and minimize time spent in services, aiming at the fastest possible solution, both in relation to hospital discharge and accommodation of clients in nursing beds, aiming at improving quality of care and the general result ${ }^{(18,21-23)}$.

Most surgical specialties presented no major variation in number of patients, except urology, with a mean increase of $173.93 \%$. The productivity of this clinic is believed to be related with a better use of its surgical hours, as well as the availability of the surgical team.

The specialties obstetrics, orthopedics and traumatology, and surgical emergency service (general surgery) had more patients. This result is related to characteristics of this hospital, which is considered a reference for high-risk pregnancy and trauma. These data were similar to those of a study conducted in a teaching hospital in Cascavel, Paraná state, in which these clinics were also responsible for a higher number of provided services ${ }^{(24)}$.

The temporal analysis has shown an ascending trend for indicators related to structure and result. The number of procedures per surgical room and patients per surgical room increased after IBRC implementation, which indicates that the surgical center was optimized; this sector is considered as a major contributor to hospital income.

The ascending trend of the structure and results indicators is presupposed to be related to the optimization of resources which were previously available in the institution, which may be observed by the increase in the number of outpatients and elective patients cared for after the implementation of IBRC with the same installed capacity.

After the implementation of IBRC, the number of urgency and elective hospitalizations increase from 5,241 to 7,457 and from 1,171 to 1,914 individuals, respectively. This increase in the number of clinical and surgical services was observed in other health institutions after the implementation of bed regulation strategies or services ${ }^{(3,25)}$.

Comparing the structure indicators between the studied institution and a similar institution after the implementation of a new management model, the number of procedures per room was higher than in this study ${ }^{(26)}$. Both hospitals were observed to present an increase in the number of procedures after the implementation of management strategies.
As for the time between HAA emission and manager authorization, a steady trend was verified for this indicator; the mean value decreased. This result is believed to be related to the articulation between IBRC and local management based on one of this service's pillars: regulation practice ${ }^{(4)}$.

Regarding the indicators "time between admission and surgery", "time between surgery and outcome", and "duration of stay", steady trends were observed. However, the institution's IBRC was observed to perform actions aiming at improving such indicators. Elective surgical patients are hospitalized in the day of the surgical procedure or as close as possible, aiming at reducing the hospitalization time, considering its relationship with a higher risk of hospital infection ${ }^{(27)}$. Also, the IBRC articulates the diverse professionals involved in care, providing verification and satisfaction of the patients' needs. Consequently, teamwork enables resolving and speeding up the necessary processes for client treatment and rehabilitation.

The mean hospital stay had a mean reduction of 1.6 days after the implementation of IBRC, even though it has presented no statistical significance. In another study, after service implementation, the mean stay of surgical patients had no major variation and a stronger decline was observed regarding clinical patients. However, the mean stay is lower than in this study, ranging from 4.00 to 5.67 days $^{(3)}$. The reduction of the indicator was also verified in other institutions ${ }^{(23,25)}$, showing to be a problem-solving service and reducing risks due to prolonged hospitalizations and anticipating the individuals' return to society.

With an increase in time between HAA and surgery, the implementation of IBRC is presupposed to have organized the line of elective surgical patients, enabling also scheduling and performing the surgical procedures of individuals with HAA which had been requested some time ago, emphasizing the importance of this service in organization and resolution of surgical cases.

An increase was observed for the mean time of process indicators (waiting time after discharge in the PACU, waiting time after discharge in the PACU for inpatients and total time in the surgical center). This result is believed to be possibly related with the increase of surgical productivity and with the hospital occupancy rate and other general indicators of the institution, although these are not the focus of this research.

In the study institution, the surgeries are started even without the physical availability of beds, aiming at reducing surgical delays, which contributes to the increase of the permanence of patients in the PACU. In outpatient procedures, the reduced nursing team is possibly the determinant factor for such increase, considering that only one collaborator performs the pre-surgical care of individuals and is responsible for pre- and post-surgical transportation.

The IBRC managers are emphasized to perform management activities to enable and speed up the bed availability in the units, prioritizing ICU discharges and the elective demand.

Among the developed actions, the direct partnership with physicians responsible for the hospitalization is emphasized. 
It enables pending treatment phases to be identified and made possible so that the patient may be discharged; daily and frequent rounds through the hospitalization units, personally following the processes of admission and discharge; using a cell phone application to immediately activate the hospitality services; providing transportation for patient transfer, and others.

In addition, such indicators are believed to be related with the delayed transfer of patients in the surgical center to inpatient or outpatient units. The transportation of patients in the institution, from Monday to Friday, is conducted by IBRC professionals and, in diverse moments, the team was reduced, which may have increased the time of surgical patients post-anesthesia discharge in the surgical center.

This increase in the number of surgical patients bears relevance, particularly when the client's flow is appropriate. For a revenue from hospitalization and surgical procedures, this flow must be appropriately regulated. In case of an elective hospitalization, the request report must be authorized before it is performed ${ }^{(28)}$. Urgency hospitalization occurs before authorization and the health institution has up to two business days from the day of hospitalization to perform report proceeding ${ }^{(28)}$.

According to the Technical Manual of the Hospital Information System, elective HAA is valid for 15 days from the date of authorization; however, with the decentralization of the processing of the Hospital Information System (HIF), the local management has increased its autonomy, extending its capacity ${ }^{(28)}$. According to the municipal contract 0216/2016, by the Municipal Government of Londrina, in which general commitments by institution and municipality, physical and qualitative objectives, and performance indicators are described, all reports of surgical procedure request must be conducted within a maximum 36 months, and those exceeding the time limit must present a justification to the municipal manager.

There was an ascending trend in patients submitted to surgical procedures with previously authorized elective HAA, showing that the IBRC organized the elective surgical patient flow in the institution. In relation to time between authorization and performance, a steady trend was observed, with an increase in the period after service implementation. However, the mean meets the time limit defined by the municipality.

The temporal analysis of indicators related to the surgical patient in the institution enables evaluating the activities and actions of the IBRC. The linear regression model is nonetheless emphasized to evaluate the inclination of a particular period and different trends could be observed in previous or posterior moments.

The effectivity of IBRC may be measured through various indicators; on the other hand, the main evaluations are related to the occupancy rate and the mean time of hospital stay $^{(2)}$. The maximum use of the indicators shows the service's performance through its results and may contribute to the reduction of resistance to its implementation.

Health institutions are complex, presenting deeply rooted routines and organizational cultures; resistance to change upon its confrontation with previous institutionally established conceptions is thus expected. The culture of efficiency in the hospital environment is emphasized to be introduced gradually; resistance tends to decrease at the same rate. The success of IBRC implementation requires synergism of force and support by institution leaders, managers, coordinators, and other professionals ${ }^{(4)}$, since adherence by the medical team and dissemination of this information are challenges which must be faced ${ }^{(3)}$.

The IBRC changes the historical and institutional context and, understanding that the change of indicators due to the actions of this service occurs gradually, follow-up of data over time is required, enabling an analysis of contributions of this service to the health institution ${ }^{(10)}$ and facilitating the identification of its frailties for the implementation of improvement strategies.

In the literature, there are few studies, especially in Brazil, approaching the changes of hospital indicators after the implementation of strategies or bed regulation, making benchmarking among institutions more difficult. In addition, process indicators (time between emission and authorization of hospitalization, time between authorization of hospitalization and surgery, time between hospital admission and surgery, time between surgery and hospitalization outcome, and waiting time in the surgical after discharge from the post-anesthesia care unit) and result (number of patients with HAA) are not commonly approached in research analyzing indicators.

The approach of process indicators is presented as an institutional diagnosis tool, since it enables demonstrating its frailties and potentials, providing the possibility of implementing strategies to enable patient flow. Thus, although regulation strategies and services play a fundamental role in hospitals, the bed management process depends on the collaboration of the whole hospital team; the synergism of the diverse professionals involved is thus indispensable to achieve the desired results.

This study has approached only the indicators related to surgical patients, enabling the presented results to be related with other general hospital indicators. Another NEPGESE member is emphasized to be performing a broader study, approaching other institutional indicators.

This study is considered to be limited by the lack of analysis of indicators per clinic and surgery cancellation, taking into account that such results may present changes when analyzed from these perspectives.

This study has presented the hospital indicators with a focus on the surgical patient after IBRC implementation, approaching some aspects still little available in the literature. The results presented in this research may serve as a support for internal and external benchmarking.

\section{CONCLUSION}

The results of the implantation and implementation of IBRC are emphasized to be gradual; also, the effectivity of its performance depends on the support by the institution's leaders, managers, and coordinators. 
The structure indicators (number of procedures per surgical room and number of patients per surgical room) presented a statistically significant change, showing a higher number of provided services and a better codification of the procedures.

The process indicators time between HAA emission and authorization, time between hospital admission and surgery, time between surgery and hospitalization outcome, time in the surgical room and duration of hospital stay presented no statistically significant changes; however, a reduction in the mean values was observed, showing an appropriate performance of the IBRC. The other process indicators (time between HAA and surgery, waiting time in the PostAnesthesia Care Unit after outpatient discharge, waiting time in the Post-Anesthesia Care Unit after inpatient discharge, and total time in the surgical center) have shown no statistical significance.

The result indicators (number of surgical patients, number of surgical inpatients, number of surgical procedures, number of patients with HAA) presented a significant statistical change, except for the mortality rate of the surgical patient.

\section{RESUMO}

Objetivo: Analisar os indicadores de paciente cirúrgico após a implantação de Núcleo Interno de Regulação de Leitos em hospital universitário. Método: Estudo longitudinal, quantitativo e retrospectivo. A coleta de dados foi realizada no sistema institucional Informação de Gestão Hospitalar, do qual foram obtidas as informações dos pacientes submetidos a procedimentos cirúrgicos entre janeiro de 2015 e junho de 2018. Para a verificação de tendência dos dados, foi utilizado modelo de regressão linear simples. Resultados: Observou-se predominância de pacientes com idade entre 20 e 39 anos e internação em caráter de urgência. Verificou-se a tendência crescente dos indicadores de estrutura quanto ao número de procedimentos cirúrgicos e de pacientes por sala operatória. Os indicadores de processo apresentaram-se estagnados. Apresentaram tendência crescente os indicadores de resultado relacionados aos números de pacientes cirúrgicos, pacientes cirúrgicos internados, procedimentos cirúrgicos e pacientes com Autorização de Internação Hospitalar. Conclusão: Observou-se alteração nos números médios dos indicadores de processo, demonstrando a atuação deste serviço. Também foram verificadas mudanças organizacionais quanto ao estabelecimento de normas, processos e fluxos.

\section{DESCRITORES}

Ocupação de Leitos; Centros Cirúrgicos; Indicadores de Serviços; Administração Hospitalar; Enfermagem de Centro Cirúrgico.

\section{RESUMEN}

Objetivo: Analizar los indicadores de los pacientes quirúrgicos tras la implantación del Comité Interno de Regulación de Camas en un hospital universitario. Método: Estudio longitudinal, cuantitativo y retrospectivo. La recolección de datos se realizó en el Sistema de Información de la Gestión Hospitalaria institucional, del cual se obtuvo la información de los pacientes sometidos a procedimientos quirúrgicos entre enero de 2015 y junio de 2018. Para verificar la tendencia de los datos, se utilizó un modelo de regresión lineal simple. Resultados: Se observó un predominio de pacientes de entre 20 y 39 años y la hospitalización de urgencia. Hubo una tendencia al alza en los indicadores de estructura relativos al número de procedimientos quirúrgicos y de pacientes por sala quirúrgica. Los indicadores de proceso fueron estables. Los indicadores de resultados relacionados con el número de pacientes quirúrgicos, los pacientes quirúrgicos hospitalizados, los procedimientos quirúrgicos y los pacientes con Autorización de Ingreso Hospitalario mostraron una tendencia al alza. Conclusión: Se observaron cambios en los valores medios de los indicadores de proceso, lo que demuestra la actuación de este servicio. También se verificaron cambios organizativos en cuanto al establecimiento de normas, procesos y flujos.

\section{DESCRIPTORES}

Ocupación de Camas; Centros Quirúrgicos; Indicadores de Servícios; Administración Hospitalaria; Enfermería de Quirófano.

\section{REFERENCES}

1. Associação Nacional dos Hospitais Privados. Livro Branco Brasil Saúde 2015: a sustentabilidade do Sistema de Saúde Brasileiro: caderno de propostas. São Paulo: ANAHP; 2014.

2. Soares VS. Analysis of the Internal Bed Regulation Committees from hospitals of a Southern Brazilian city. Einstein (São Paulo). 2017;15(3):339-43. doi: http://dx.doi.org/10.1590/s1679-45082017gs3878

3. Faria E, Ryuko K, Costa A, Santos MA, Fumio MK. Nova abordagem de gerenciamento de leitos associada à agenda cirúrgica. Rev Adm Saúde. 2010;12(47):63-70.

4. Brasil. Ministério da Saúde; Secretaria de Atenção à Saúde, Departamento de Atenção Hospitalar e de Urgência. Manual de implantação e implementação: núcleo interno de regulação para hospitais gerais e especializados. Brasília: MS; 2017.

5. Walker C.; Kappus Kelli; Hall Norma. Strategies for improving patient throughput in an acute care setting resulting in improved outcomes: a systematic review. Nurs Econ. 2016;34(6):227-88.

6. Universidade Federal da Grande Dourados. Hospital Universitário. HU é o primeiro hospital público da região a ter Núcleo Interno de Regulação [Internet]. Dourados; 2020 [citado 2020 dez. 02]. Disponível em: http://www2.ebserh.gov.br/web/hu-ufgd/noticia-destaque/-/ asset_publisher/R45hP6AcdwLN/content/hu-e-o-primeiro-hospital-publico-da-regiao-a-ter-nucleo-interno-de-regulacao

7. Grübler M, Costa CA, Righi RR, Rigo SJ, Chiwiacowsky LD. A hospital bed allocation hybrid model based on situation awareness. Comput Inform Nurs. 2018;36(5):249-255. doi: 10.1097/CIN.0000000000000421.

8. Brasil. Ministério da Saúde. Portaria n. 1.663, de agosto de 2012. Dispõe sobre o Programa SOS Emergências no âmbito da Rede de Atenção às Urgências e Emergências (RUE). Brasília: MS; 2012

9. Brasíl Ministério da Saúde. Manual Instrutivo para Adesão dos Hospitais do S.O.S Emergências ao Programa Melhor em Casa. Brasília: MS; 2013.

10. Rodrigues LC, Juliani CMC. Resultado da implantação de um Núcleo Interno de Regulação de Leitos nos indicadores administrativoassistenciais em um hospital de ensino. Einstein (São Paulo). 2015;13(1):96-102. doi: https://doi.org/10.1590/S1679- 45082015GS3235. 
11. Brasil. Ministério da Saúde; Secretaria Executiva Núcleo Técnico da Política Nacional de Humanização. HumanizaSUS: Política Nacional de Humanização [Internet]. Brasília: MS; 2004 [citado 2019 out. 11]. Disponível em: http://bvsms.saude.gov.br/bvs/publicacoes/ humanizasus_2004.pdf

12. Souza MA, Rama AR, Ribeiro A, Figueiredo AB, Osório RC, Salgado Junior W. Implantação da central de agendamento: uma estratégia de humanização no HERiberião. Rev QualidadeHC [Internet]. 2017 [citado 2019 out. 11];102-08. Disponível em: http://www.hcrp.usp. br/revistaqualidade/uploads/Artigos/137/137.pdf

13. Polit DF, Beck CT. Fundamentos da pesquisa em enfermagem: avaliação de evidências para a prática de enfermagem. $7^{\mathrm{a}}$ ed. Porto Alegre: Artmed; 2011.

14. Donabedian A. The quality of care: how can it be assessed? JAMA. 1988;260(12):1743-8. doi: 10.1001/jama.1988.03410120089033

15. Field A. Descobrindo a estatística usando o SPSS. Porto Alegre: Artmed; 2009.

16. Rodrigues AIG, Korinfsky JP, Santos ADB, Oliveira ANS, Almeida LR, Moura LA. Perfil dos usuários atendidos no serviço de emergência em hospital universitário de Pernambuco. Rev Baiana Saúde Pública. 2015;39(1):13-24. doi: http://dx.doi.org/10.5327/Z0100-02332015390100003

17. Ervatti IR, Borges GM, Jardim AP, organizadores. Mudança demográfica no Brasil no início do século XXI: subsídios para as projeções da população [Internet]. Rio de Janeiro: IBGE; 2015 [citado 2019 set. 10]. Disponível em: https://biblioteca.ibge.gov.br/visualizacao/livros/ liv93322.pdf

18. Richardson DB, Brockman K, Abigail A, Hollis GJ. Effects of a hospital-wide intervention on emergency department crowding and quality: a prospective study. Emerg Med Aust. 2017;29(4):415-20. doi: https://doi.org/10.1111/1742-6723.12771

19. Gomes LL, Volpe FM. O perfil das internações clínicas e cirúrgicas dos hospitais gerais da rede FHEMIG. Rev Med Minas Gerais. 2018;28 Supl 5:e-S280513.

20. Caluête MEE, Alves EVC, Araújo NL, Costa MBS, Santos SR. Caracterização dos procedimentos cirúrgicos realizados em idosos. Rev Enferm UFPE On line. 2015;9(4):7193-201. doi: http://dx.doi.org/10.5205/reuol.7275-62744-1-SM.0904201502

21. Crilly JL, Boyle J, Jessup M, Wallis M, Lind J, Green D, et al. The implementation and evaluation of the patient admission prediction tool: assessing its impact on decision-making strategies and patient flow outcomes in 2 Australian hospitals. Qual Manag Health Care. 2015;24(4):169-76. doi: https://doi.org/10.1097/QMH.0000000000000070

22. Khalifa M. Improving emergency room performance by reducing patients' length of stay. Stud Health Technol Inform. 2015;213:41-4. doi: https://doi.org/10.3233/978-1-61499-538-8-41

23. Sajadi HS, Sajadi ZS, Sajadi FA, Hadi M, Zahmatkesh M. The comparison of hospitals' performance indicators before and after the Iran's hospital care transformations plan. J Educ Health Promot. 2017;6:89. doi: https://doi.org/10.4103/jehp.jehp_134_16

24. Anchieta DW, Matos F, Alves D, Santos R, Oliveira J, Dal Molin T. Caracterização das infecções de sítio cirúrgico em um hospital público de ensino na cidade de Cascavel, Paraná. Vigilância Sanitária Debate. 2019;7(3):31-36. doi: https://doi.org/10.22239/2317-269x.01277

25. Adlington K, Brown J, Ralph L. Better care: reducing length of stay and bed occupancy on an older adult psychiatric ward. BMJ Open Quality. 2018;7:e00149. doi: 10.1136/bmjoq-2017-000149

26. Gaspar AF, Martone T, Carraro DC, Ferreira GSA, Ferreira-Filho JA, Cardoso R, et al. Impacto de um novo modelo de gestão no bloco cirúrgico de um hospital universitário terciário. Medicina (Ribeirão Preto). 2015;48(1):33-40. doi: http://dx.doi.org/10.11606/ issn.2176-7262.v48i1p33-40

27. Brasil. Ministério da Saúde; Agência Nacional de Vigilância Sanitária. Assistência segura: uma reflexão teórica aplicada à prática. Brasília: ANVISA; 2017.

28. Brasil. Ministério da Saúde; Secretária de Atenção à Saúde, Departamento de Regulação, Avaliação e Controle. Manual técnico do Sistema de Informação Hospitalar. Brasília: MS; 2007. 